\section{FULL LENGTH RESEARCH ARTICLE \\ PERFORMANCE OF BROILER CHICKENS FED ON LIMA BEAN, GROUNDNUT AND SOYBEAN DIETS}

\author{
*I. ACHI1: M. A. ADELANWA2 \& A. B. AHMED 3 \\ ${ }^{1}$ Ministry of Education \\ Kaduna Inspectorate Division \\ Kaduna Nigeria \\ ${ }^{2}$ Department of Biological Sciences \\ $A B \cup$ Zaria, Nigeria \\ ${ }^{3}$ Department of Biological Sciences \\ Kaduna State University \\ PMB 2339 \\ Kaduna, Nigeria \\ *(corresponding author) \\ isaac_achi@yahoo.co.uk
}

\begin{abstract}
Experimental diets were formulated using lima bean (Phaseolus lunatus Linn) groundnut (Arachis hypogeae Linn) and soybean (Glacin max Linn) mixed in varying proportions to supply $23 \%$ crude protein (CP) for starter and $20 \%$ crude protein (CP) for finisher diets. Proximate analysis of the diets revealed a generally lower protein content than the calculated values. Among the 7 formulated diets, the soybean meal had the highest crude protein compared to others without it. While the energy given components of the experimental diets were higher, with groundnut meal diets recording the highest value, the crude ash and fibre content were lower than the control diet. The growth performance of 144 nine-day old broiler chickens fed on the experimental diets for 8 weeks were compared with control group fed commercial Guinea Feed. Birds consumed significantly less $(P<0.05)$ of the experimental diets than those fed control diets. There was no significant difference $(P>0.05)$ in terms of weight gain, feed conversion ratio and protein efficiency in the performance of birds fed on soybean diets compared to control diet. Weight gain between the birds fed with lima beans and groundnut diets was significantly different $(P<0.05)$ compared to the control group.
\end{abstract}

Key words: Broiler chicken, Lima bean, Groundnut, Soybean, productivity, Nigeria

\section{INTRODUCTION}

The profitable management of broiler chicks requires knowledge of the nutritional requirements at various stages of growth. This type of information is necessary towards achieving maximum biological and economic efficiency in the use of feed resources since the rapid expansion of the livestock industry depends to a large extent on the availability of good quality feeds at reasonably cheap prices, particularly for the monogastric animal species such as poultry and pigs whose performance depends on the use of concentrated balance ration (Duru 1993).

Ravindran (1995) estimated that up to $65 \%$ of the production cost incurred by poultry farmers under small farm conditions are due to feeding. Consequently, the cost of feed ingredients remains the major determinant of profit margins in poultry farming in tropical developing countries where the situation is further worsened by the heavy dependent on imported feed components (Akinmutimi et al. 2002). Fishmeal which is an essential dietary component of poultry feed is often imported while soybean and groundnut are expensive (Ojewola \& Udom
2005). One way out of this predicament is the development of dietary formulations, which allow locally available ingredients to be used that will reduce dependence on imported feedstuff (Emenalon \& Udedibie 1998). One option is the search for alternative feed ingredients among the leguminous seeds as valuable protein sources for animals to miminise the use of soybean that has become too costly. Unfortunately in Nigeria, only little attention has been paid to the incorporation of the locally available legumes into poultry feeds despite the fact that many species of leguminous family are sources of cheap protein for animals (Lopez Bellido 1994). This work is aimed at evaluating the performance of broilers fed on experimental diets formulated by mixing bloodmeal (animal protein) with soybean, limabean and groundnut, either singly or combined (plant protein) at a ratio of $1: 3$

\section{MATERIALS AND METHOD}

Experimental birds and their management: The Anak 2000 strain of commercial broiler chickens was used in all trials. The birds were first acclimatized for 9 days on commercial Guinea Feed broiler starter mash.

A total of 144 birds were divided into 8 groups of 6 birds each in 3 replicated and housed in a deep litter floor laboratory. The floor was cleaned weekly during which the beddings were changed. The birds in group 1-7 were fed with the experimental diets ad-libitum while group 8 was fed with commercial guinea feed which serves as control diet. The birds were fed with starter mash during week 1-3 and with finisher diet during week 4-8. All other routine management practices of vaccinations and drug administration were observed

Experimental diets: The experimental diets 1-7 were formulated by combining bloodmeal (as the animal protein) with soybean, limabean and groundnut either singly or combined (as plant protein) at a ratio of $1: 3$ to provide $23 \%$ and $20 \%$ crude protein for the starter and finisher mash. Calculations were done using the algebraic method to obtain the quantity shown in Table 1 and 2. The salt, vitamin mineral [VM] premix and bone meal were fixed at $0.25 \%, 0.25 \%$ and $3.0 \%$ respectively.

Parameters measured: The criteria used to measure growth were increase in weight and Protein Efficiency Ratio (PER). Feed Conversion Ratio (FCR) was calculated to determine the efficiency of the diets. The weight of each bird in each group was taken on weekly basis and food consumed was recorded daily.

Chemical analysis of experiment diets: The experimental diets were chemically analyzed to determine the crude protein, crude fibre, ash and fat according to procedure of AOAC (1980) while the Nitrogen Free Extract (NFE) was calculated.

Analysis of data collected: Data collected were analysed using analysis of variance (ANOVA) (Steel \& Torrie 1980) while means where compared by Duncan's Multiple Range Test (Duncan 1955). 
RESULTS

The nutrient and chemical composition of the 7 experimental diets for both the starter and finisher is shown in Tables 1 and 2 while data on performance on of the birds on the various diets are given in Table 3.

TABLE 1. NUTRIENT COMPOSITION OF STARTER DIETS (\%)

\begin{tabular}{|c|c|c|c|c|c|c|c|c|}
\hline Ingredients & Diet 1 & Diet 2 & Diet 3 & Diet 4 & Diet 5 & Diet 6 & Diet 7 & $\begin{array}{c}\text { Diet } 8 \\
\text { (Control) }\end{array}$ \\
\hline Maize & 42.89 & 58.77 & 50.2 & 50.83 & 46.55 & 54.49 & 50.62 & \\
\hline Blood meal & 13.40 & 9.43 & 11.58 & 11.42 & 12.49 & 10.51 & 11.47 & \\
\hline Lima bean meal & 40.21 & - & - & 20.11 & 20.11 & - & 13.43 & \\
\hline Soybean meal & - & 28.3 & - & 14.15 & - & 14.15 & 9.43 & \\
\hline Groundnut meal & - & - & 34.72 & - & 17.36 & 17.36 & 11.58 & \\
\hline Bone meal & 3.0 & 3.0 & 3.0 & 3.0 & 3.0 & 3.0 & 3.0 & \\
\hline VM premix & 0.25 & 0.25 & 0.25 & 0.25 & 0.25 & 0.25 & 0.25 & \\
\hline Salt & 0.25 & 0.25 & 0.25 & 0.25 & 0.25 & 0.25 & 0.25 & \\
\hline Total & 100.00 & 100.00 & 100.00 & 100.00 & 100.00 & 100.00 & 100.00 & \\
\hline \multicolumn{9}{|l|}{$\begin{array}{l}\text { Determined } \\
\text { values }\end{array}$} \\
\hline Crude Protein & 21.96 & 22.57 & 21.08 & 22.44 & 21.31 & 22.21 & 21.98 & 22.13 \\
\hline Crude Fibre & 3.6 & 4.09 & 5.22 & 5.32 & 4.64 & 6.03 & 7.25 & 9.9 \\
\hline Crude Fat & 1.56 & 4.01 & 13.64 & 3.64 & 6.11 & 8.19 & 6.25 & 7.2 \\
\hline Ash & 6.9 & 6.63 & 5.47 & 3.67 & 6.17 & 7.46 & 7.94 & 9.19 \\
\hline NFE & 57.53 & 55.07 & 44.38 & 55.27 & 53.95 & 49.12 & 49.09 & 42.9 \\
\hline
\end{tabular}

TABLE 2. NUTRIENT COMPOSITION OF FINISHER DIETS (\%)

\begin{tabular}{|c|c|c|c|c|c|c|c|c|}
\hline Ingredients & Diet 1 & Diet 2 & Diet 3 & Diet 4 & Diet 5 & Diet 6 & Diet 7 & $\begin{array}{c}\text { Diet } 8 \\
\text { (Control) }\end{array}$ \\
\hline Maize & 53.41 & 66.18 & 59.29 & 59.80 & 56.35 & 62.74 & 59.63 & \\
\hline Blood meal & 10.75 & 7.58 & 9.30 & 9.17 & 10.03 & 8.44 & 9.21 & \\
\hline Lima bean meal & 32.34 & - & - & 16.17 & 16.17 & - & 10.78 & \\
\hline Soybean meal & - & 22.74 & - & 11.37 & - & 11.37 & 7.58 & \\
\hline Groundnut meal & - & - & 27.91 & - & 13.96 & 13.96 & 9.30 & \\
\hline Bone meal & 3.0 & 3.0 & 3.0 & 3.0 & 3.0 & 3.0 & 3.0 & \\
\hline VM premix & 0.25 & 0.25 & 0.25 & 0.25 & 0.25 & 0.25 & 0.25 & \\
\hline Salt & 0.25 & 0.25 & 0.25 & 0.25 & 0.25 & 0.25 & 0.25 & \\
\hline Total & 100.00 & 100.00 & 100.00 & 100.00 & 100.00 & 100.00 & 100.00 & \\
\hline \multicolumn{9}{|l|}{$\begin{array}{l}\text { Determined } \\
\text { values }\end{array}$} \\
\hline Crude Protein & 19.2 & 20.67 & 18.73 & 20.76 & 18.95 & 20.17 & 19.74 & 18.06 \\
\hline Crude Fibre & 6.8 & 7.34 & 8.33 & 8.39 & 8.69 & 9.51 & 10.38 & 12.98 \\
\hline Crude Fat & 0.88 & 3.8 & 12.33 & 2.57 & 6.63 & 9.1 & 6.58 & 6.47 \\
\hline Ash & 5.52 & 8.15 & 6.29 & 3.78 & 5.31 & 6.68 & 2.99 & 8.46 \\
\hline NFE & 57.59 & 50.6 & 45.57 & 54.47 & 50.93 & 45.45 & 49.61 & 46.12 \\
\hline
\end{tabular}

TABLE 3 INITIAL AND FINAL WEIGHT GAIN, FEED CONVERSION RATIO, PROTEIN EFFICIENCY, PERCENTAGE DEATH RATE AND FOOD CONSUMED PER BIRD

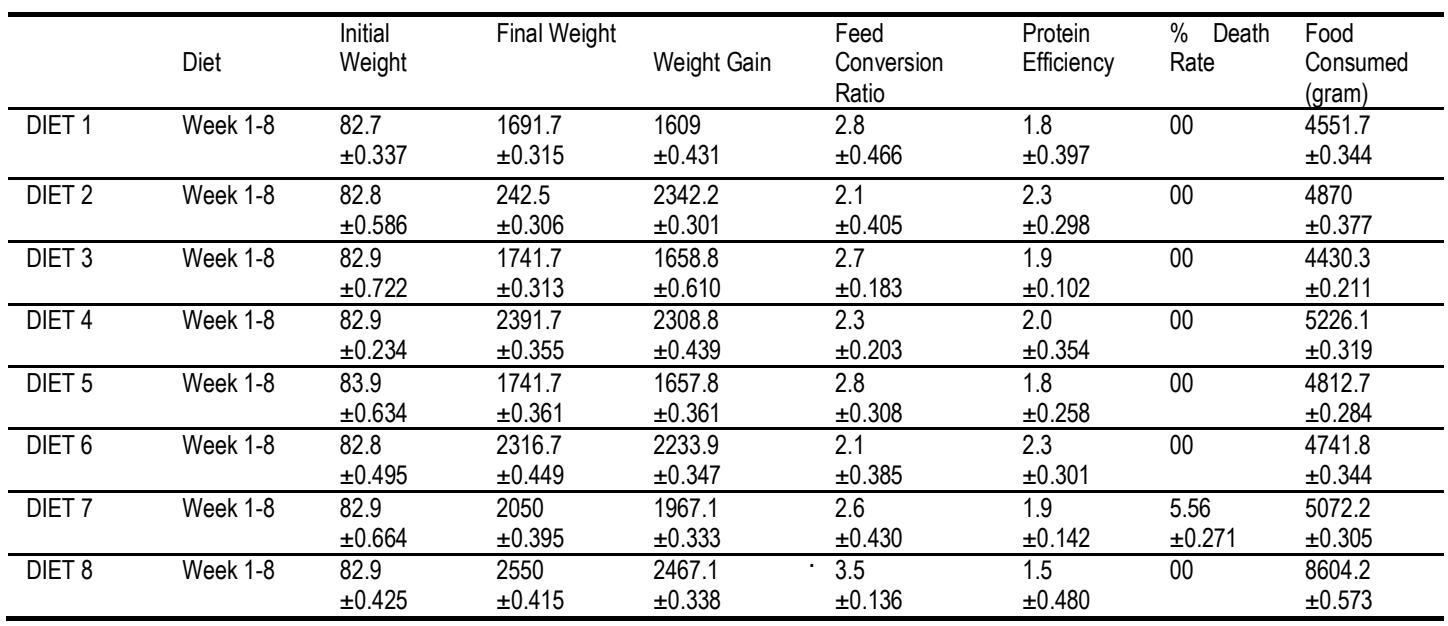


The calculated crude protein (CP) for the test diets ranged from $21.08-22.57 \%$ while the control diet 8 had $22.13 \%$. Calculated crude protein for the finisher diets ranged from 18.87-20.76\% while the control had $18.06 \%$. For both starter and finisher, diet 3 gave the lowest value and diet 2 recorded the highest value. For the starter experimental diets, diets 1,3,5 and 7 had values below $22.13 \%$ of the control while all the diets in the finisher diets had values above $18.06 \%$ of the control.

The crude fat (CF) was generally lower than the value of the control in all the test diets for both the starter and finisher diets. Crude fat values ranged from $1.56-13.64 \%$ among the test diets in the starter with the control diet 8 having a value of $7.2 \%$. For the finisher diets, it ranged from $0.88-12.33 \%$ with $6.47 \%$ for the control.

Percentage ash for the starter diets ranged from 3.67-7.94\% and a control value of $9.19 \%$. For the finisher test diets, it ranged from $2.99 \%$ (diet 7 ) to $8.15 \%$ (diet 2) and a control value of $8.46 \%$.

NFE values were generally higher in starter test diets (range $44.38-57.53 \%$ ) than the control with $42.9 \%$. For the finisher, diets 3 and 6 had values lower than the control (46.12\%) while the test diets had values above the control.

The highest weight gain was recorded in control diet 8 , followed by diets 2, 4, 6 and 7 respectively. The lowest weight gain was recorded in diet 1 and was slightly lower than diet 5 and 3 (Table 3) ANOVA of weekly weight gain per bird (week 1-8) showed significant difference $(P<0.05)$ between the diets. Duncans mean grouping indicated no significant difference between the mean weight gain of diets $8,2,4,6$ and 7 but a significant difference in diets 3,5 and 1

The food conversion ratio recorded the best value in diets 2 and 6 (Table 3). Next to this was diet 4, followed by diets 7, 3 and 1 and 5 . The poorest food conversion ratio was recorded in diet 8 (control). The analysis of variance of food conversion ratio indicated an insignificant difference between the diets.

Mortality rate was approximately $6.0 \%$ from birds fed on diet 7 (Table 3).

\section{DISCUSSION}

The results of the chemical analysis of the experimental diets showed a variation in the proximate composition of crude protein content which was generally lower than the calculated value of $23 \%$ for starter diets and 20\% for the finisher diets. Despite this low values, the crude protein contents of the finisher diets falls within the range recommended by Olumo (1979) but fall short of the values given by Aduku (1993). The differences observed in the crude protein content between diets may be due to differences in the seeds, differences in soil fertility, time of harvest and genetic constitution (Santosh 1991; Ojewole et al. 2005).

While the composition of crude fibre in both the experimental and control diet are within the values of Olumo (1979), it was higher than the $5.0 \%$ maximum in the finisher diets recommended by same author.

Fat as a source of energy in broiler diet shows variation in composition within the diets. While the fat content in the starter and finisher diets containing lima bean were low (Olumo 1979, NRC1994), the values were high in the diets containing groundnut probably because of the seeds used. Earlier works (Purseglove 1974, Asiedu 1989) confirmed that groundnut has higher fat than soybean and lima bean.

The results of this work showed that diet 4 had increased feed intake more than others, which could be due to low energy content of the diet as indicated by the low crude fat values. This means that feed intake alone may not necessarily be a major factor in growth enhancement. This finding is in agreement with Olumo (1979) and Scott et al. (1982) that chickens consume food to satisfy their energy requirements and within a certain energy range, food consumption decreases with increase in energy level.

The poor growth recorded upon feeding diets 1, 3 and 5 could therefore not necessarily be attributed to reduced feed intake alone but a combination of several factors, agreeing with (Sadeghi et al. 2004) that growth depression from feeding grain legumes is usually due to more than one factor. For example diets 1 and 3 had similar feed intake and similar growth rate, while diets 2 and 5 had similar feed intake but body weight was $41 \%$ higher in diet 2 . The higher values of weight gain obtained in the experimental diets containing soybean as the vegetable protein could be owing to the quality of the protein in such diets. Similar reason was advanced to explain increased weight gain in broiler chickens fed cooked Mucuna seed meal (Carew et al, 1998; Anele 2002; Akinmutimi \& Okwu 2006). Both Olumo (1979) and Scott et al. (1982) showed that birds fed with highenergy food substances such as total digestible carbohydrate and fat, consumed less food compared to those fed with less energy food substances and that chickens eat food to satisfy their energy requirements which decreases with increase in energy level within a certain energy range as demonstrated in diets 2, 4 and 6 with high Protein Efficiency and corresponding low figures of Feed Conversion ratio.

The mortality of birds fed experimental diets was lower than reported earlier (Ologhobo et al. 1993), a good indication of the potentiality of the experimental diets for growth performance.

It is concluded that most of the test diets formulated in this studies produced results that with further feeding trials could be improved to meet production requirements.

\section{REFERENCES}

Aduku, A. O. 1993. Tropical Feedstuff Analysis Table. Ahamdu Bello University, Samara-Zaria, Unpublished document:1-4

Akinmutimi, A. H.; Abasiekong, S. F. \& Izundu, R. O. 2002 Effect of processing on metabolisability of energy and protir content of sword bean (Canavalia gladiata) using muscovry duck (Carina muschata). Tropical Journal of Animal Science $5: 51-56$ 
Akinmutimi, A. H. \& Okwu, N. D. 2006. Effect of quantitative substitution of cooked Mucuna utilis seed meal for soybean meal in broiler finisher diet. International Journal of Poultry Science 5(5):477-481

Anele, U. Y. 2002. The effects of raw Mucuna utilis extract on broiler birds. B.Sc. Thesis. Michael Okpara University of Agriculture, Umudike.

A.O.A.C. 1980. Association of Analytical Chemists. Official Methods of Analysis. 13 th Washington D. C.

Asiedu, J. J. 1989. Processing Tropical Crops. A technological approach publication, Macmillan Educ. Ltd., 1 ${ }^{\text {st }} \mathrm{Ed}$

Carew, L. B.; Alster, F. \& Gernat, A. G. 1998. Consumption of raw velvet beans (Mununa pruriens) alters organ weights and intestinal lengths in broiler. Poultry Science, 77 (suppl.1): 56.

Duncan, D. B. 1955. Multiple Range and Multiple F-tests. Biometrics 11: 1-42.

Duru, S. 1993. Evaluation of groundnut plant meal (Harawa) as egg-yolk pigment and its effect on the performance of egg type chicks, M.Sc. Thesis ABU Zaria Nigeria

Emenalon, O. O. \& Udedibie, A. B. I. 1998. Effect of dietary raw, cooked and toasted Mucuna pruriens seeds (velvet bean) on the performance of finisher broiler. Nigerian Journal of Animal Production 25:115-119.

López Bellido, L. 1994. Grain legumes for animal feeds. In : J.E. Hernándo Bermejo and J. León (eds.).Neglected Crops: 1492 from a Different Perspective. Plant Production and Protection Series No. 26. FAO, Rome, Italy: 273-288.

National Research Council (NRC) 1994. Nutrient Requirement of Poultry. $9^{\text {th }}$ edn. National Academic Press, Washington D.C.
Ologhobo, A. D.; Apata, A. \& Oyejide, A. 1993. Utilization of Jackbean (Canavalia ensiformis) and Jackbean Fraction in diets of broiler chickens. Britich Poultry Journal 34:323-337.

Olumo, J. M. 1979. Nutrient requirement and nutrient contents of feed ingredients. Proceeding of a Conference on Poultry Production in Nigeria. Edited by J. M. Olumo, S. A. Offiong, V. Buvansudran \& O. A. Osimono.

Ojewola, G. S. \& Udom, S. F. 2005. Chemical evaluation of the nutrient composition of some unconventional animal protein sources. International Journal of Poultry Science 4(10);745-747

Ojewola, G. S.; Okoye, F. C. \& Ukoha, O. A. 2005. Comparative Utilization of three animal protein sources by broiler chickens. International Journal of Poultry Science, 4:462-467.

Purseglove, J. W. 1974. Tropical Crops Monocotyledons Longman Publication Company

Ravindran, V. 1995. Evaluation of a Layer diet formulated from non-conventional feeding stuffs. British Poultry Science 36:165170 .

Sadeghi, G.; Samie, A.; Pourreza, J. \& Rahmani, H. R. 2004. Canavanine content and toxicity of raw and treated bitter vetch (Vicia ervilia) seeds for broiler chicken. International Journal of Poultry Science 3 (8): 522-529

Santosh, P. L. 1991. Concept in the formulation and preparation of a complete fish diet. In.: Fish nutrition research in Africa, Proceeding of the fourth African fish nutrition workshop edited by S.S. De Silva:1-12

Scott, M. L.; Neishein, M. C. \& Young, N. T. 1982. Nutrition of the chicken. $3^{\text {rd }}$ edn. ML Scott \& Ass. Ithaca, New York.

Steel, R. G. \& Torrie, J. H. 1980. Principles and procedures of statistics $2^{\text {nd }}$ ed. Mcgrand Hill Book Company Inc. NY 